\title{
Latin America's Decentred Economic Regionalism: From the FTAA to the Pacific Alliance
}

\section{Jean Santos Lima*}

\begin{abstract}
In this article, I examine Latin American regionalism from the collapse of the Free Trade Area of the Americas (FTAA) to the emergence and development of the Pacific Alliance (PA) in the period 2005 to 2015. For most of the research, I use the main economic blocs in the region, Mercosur as well as the PA, as the units of analysis. The main findings are that since the FTAA's collapse, integration processes have become more heterogeneous; that Mercosur and the PA contrast with one another in political-economic terms; that the Brazilian project of establishing a post-liberal/ post-hegemonic regionalism in South America has not succeeded; and that regional demand for Brazilian products is at risk of shifting to other markets in the medium to long term, thus further undermining its aspirations towards regional leadership. All of this is evidence of a decentred economic regionalism - that is, a form of regionalism in which no single state is in central command, or has enough followers to assume leadership and establish a dominant conception of integration and regional cooperation. Other factors contributing to this decentralisation are the poor economic performance of Brazil and Mexico, and the US government's changed attitude towards trade relations with Latin America. Despite this, I argue that Latin American countries do need to strengthen cooperation within and among these regional blocs, aimed at promoting their joint global competitiveness. This will require cooperation rather than coercion, and networks and connectivity rather than hierarchies.
\end{abstract}

Keywords: Regionalism; Regional integration; Growth; Latin America; Pacific Alliance; FTAA.

\section{Introduction}

Since the collapse of the Free Trade Area of the Americas (FTAA), Latin America ${ }^{1}$ has undergone profound changes that have been reflected in the character of regionalism and regional integration. Relations with the USA have naturally played a central role in the politics and economics of the subcontinent, and the shift from an open regionalism in the

University of Brasília (UnB)-IREL, Brasília-DF, Brazil; jeanlima.91@gmail.com. ORCID iD 0000-00034758-2389. 
1990 s to post-liberal/post-hegemonic regionalism in the 2000 s provided Brazil with an attractive opportunity to assume a leadership role in South America.

Overall, 'regionalism fuels regionalism, since, for the nations that fall outside the main processes, the costs of exclusion seem to increase. The new era on the continent provides us with a compelling opportunity to describe and analyse the political economy of contemporary Latin American regionalism, from the proposed hemispheric integration to the current regional heterogeneity.

I examine the heterogeneous Latin American regionalism in a mainly economic but also political sense, from the collapse of the FTAA to the emergence and initial development of the Pacific Alliance (Alianza del Pacífico), largely in the period from 2005 to 2015. For most of the research, I refer to the main economic blocs of the region, the Common Market of the South (Mercosur) and the contrasting PA as the units of analysis. Although there are a number of other experiences of regional integration in Latin America, Mercosur and the PA together cover most of the region's economy, and have economic and trade interests as the main pillars of integration, albeit with different ambitions. Other organisations such as the Community of Latin American and Caribbean States (CELAC) and the Union of South American Nations (UNASUR) ${ }^{2}$ have more diverse interests, seeking to serve as mechanisms for regional cooperation and political dialogue, including the resolution of conflicts among countries.

I argue that the heterogeneity of integration processes, the contrast in the political economies of various regional blocs, the unaccomplished Brazilian project of establishing a post-liberal/post-hegemonic regionalism, and the risk of a longer-term shift of regional demand for Brazilian goods and services to other markets are all evidence of a decentred economic regionalism - i.e., a form of regionalism without a single state assuming central control, or with enough followers to assume leadership and establish a predominant conception of integration and regional cooperation. There is a noticeable historical heterogeneity within the region in terms of the different models of external engagement, development strategies, and relations between states and markets. Should they be poorly managed, these differences might further hamper efforts to address the historical lack of economic regional integration. I argue that, despite this heterogeneity, the adverse international outlook for Latin American economies implies a greater need for cooperation and integration on the subcontinent and among the various regional blocs, aimed at enhancing the global competitiveness of Latin America as a whole.

I do not argue that the PA and the economic profiles of its member countries constitute models that other Latin American countries should ideally pursue, or that this kind of integration will make its members more successful. However, it is clear that the Mercosur model should allow its members to benefit individually from their national endowments as well as from pooled regional capacities. All Latin American countries should improve their internal productive capacities through long-term policies, utilising global integration as a means of expanding their competencies, know-how, and markets. This is a way of combining regionalism with the dynamics of globalisation, which has increasingly preoccupied scholars and decision-makers alike. 
The article engages with the international political economy of regionalism as well as (largely economic) cooperation and integration in Latin America. ${ }^{3}$ It is also relevant to the field of 'comparative regionalism,' an avenue of enquiry that has been consolidated in studies of International Political Economy (IPE), aimed at understanding the diverse range of regionalisms that have followed the 'new regionalism' of the 1990s and 2000s (Acharya 2012).

According to Söderbaum (2015: 23), comparative regionalism recognises regions as porous, overlapping and plural; identifies emerging dialogues among them; compares them to others; and acknowledges the emergence of non-Eurocentric concerns, which, in his view, is contextually more sensitive and conceptually less rigid. Besides comparing regions, comparative regionalism lends itself to studying regionalisms 'within' regions, thereby aiding an understanding of the complex and volatile Latin American political and economic spectrum.

This article is structured as follows. First, following some conceptual remarks, it examines the collapse of the FTAA (ALCA) as well as the - mainly Brazilian - attempt to establish a post-liberal/post-hegemonic regionalism in Latin America to supersede the project of hemispheric integration. Second, it examines the emergence of the PA, paying particular attention to the challenges surrounding the integration of the bloc and the model of open regionalism. Given that open regionalism is to some extent opposed to 'post-liberal' or 'post-hegemonic' regionalism, the comparison between Mercosur and the PA allows inferences about decentred economic regionalism in Latin America.

Third, the article examines the extent to which the political-economic models underpinning the PA and the economies of its member states contrast with those of Mercosur and its member states, defying Brazilian regional objectives in the process.

Fourth, it examines shifts in Brazilian export preferences by recording Brazilian exports to PA and Mercosur member states in three selected years $(2005,2010,2015)$, compared to Chinese and US exports. The expansion of a country's trade relations with its neighbours plays a key role in establishing regional leadership and interdependence. This analysis shows that Brazil has failed to consolidate its role as primary exporter to other countries in the region, which has undermined its attempt to assume a leading regional role.

Fifth, it analyses important international trends, including the end of the commodity boom and the revival of protectionism, which generates a greater need for integration, even in a decentred form. Some final considerations follow.

\section{The collapse of the FTAA and the emergence of post-liberal/post- hegemonic regionalism}

I need to start with some conceptual remarks. I understand 'regional integration' as the process of lowering or eliminating barriers to the flow of capital, goods and services, people, and all other factors of production among countries. I understand 'bloc' as a group of states with common objectives, including regional integration. I understand 'regionalism' as a broader movement or phenomenon, involving, in the words of Soares de Lima 
(2013: 178), 'processes of cooperation in diverse areas, including the military, political, economic, energy, and technical fields, which reflect foreign policy priorities, including the geostrategic dimension.'

It is also common to recognise 'waves' of regionalism, which helps to situate the formation of integration blocs in time. The first wave started in the wake of World War Two, continued through the 1970s, and spanned treaties and organisations until the early 1980s. In Latina America, this wave was characterised by the promotion of closed regionalism, notably the adoption of protectionist practices as a strategy for regional economic development (Devlin and Giordano 2004).

The second wave started in the late 1980s, when the Cold War was about to end, and globalisation accelerated. Regional integration gained further momentum, spurred by the search for improved international economic insertion. This wave was marked by the promotion of open regionalism, with regional liberalisation seen as a step towards multilateral liberalisation as well as inter-regional negotiations, even though this model was again broadly questioned in the early 2000s (Herz and Hoffman 2004).

Key moments in the second wave were the establishment of Mercosur in 1991, the adoption of the Constitution of the European Union in 1992, the establishment of a free trade area under the Association of Southeast Asian Nations (ASEAN), also in 1992, and the adoption of the North American Free Trade Agreement (NAFTA) in 1994.

In this context, the USA began to push for renewed regional integration. The government of George H W Bush (1989-1993) launched an 'Initiative for the Americas' that sought to promote integration, market economies, and political democracy. Commercial integration was instrumentalised through the Free Trade Area of the Americas (FTAA), as it was labelled by the Clinton government, which was aimed at gradually eliminating tariff barriers on the American continent as a whole, and possibly establishing the world's largest free trade zone, encompassing 34 countries.

With this goal in mind, the first meeting between American heads of state, the First Summit of the Americas, was held in Miami in 1994. The first major international meeting of heads of state in the post-Cold War period, its main objective was to promote negotiations leading to hemispheric integration. It was a good moment for advancing regional negotiations, as many Latin American leaders were now more economically orthodox and liberal than earlier ones. In the course of the negotiations, the USA proposed moving beyond liberalisation of the exchange of goods towards 'second-generation' issues such as services, intellectual property rights, and public purchases. Ambitious ideas were also raised about transnational regulation, including systematising and harmonising rules of origin.

In 2005 - the year in which the FTAA was meant to be established - the project failed at the Fourth Summit of the Americas in Mar del Plata, led jointly by the USA and Brazil. Differences in negotiating positions had already become apparent at the XVII meeting of the Committee for Commercial Negotiations (CNC) in Puebla in Mexico in 2004, exemplified by the Brazilian proposal for an 'FTAA lite.'

Various reasons for terminating the negotiations emerged. Following September 11 and the declaration of the US-led 'War against Terror', the Bush government was less in- 
terested in negotiating with Latin American countries, and less inclined to lock horns with the country's strong agricultural sector, which was reluctant to liberalise markets.

Conditions in South America also did not favour the negotiations, and key interests were opposed and even explicitly hostile to the project. New leftist leaders had risen to power in the region. More heterodox or nationalist than those in the 1990s, they sought to strengthen the economic role of the state rather than the market, and aspired towards increased intervention, both domestically and internationally, 'in search of a regional affirmation in the South American realm, and greater autonomy in relations with the United States' (Ayerbe 2008: 9). They included Hugo Chavez in Venezuela (1999); Lula da Silva in Brazil (2003), even though economic policies during his first term continued some of the previous Cardoso government; Nestor Kirchner in Argentina (also in 2003); and Evo Morales in Bolivia (2005).

Their governments promoted the principle of national sovereignty, which became even more evident with the use of the terms 'post-hegemonic regionalism' or 'post-liberal regionalism.' According to Riggirozzi and Tussie (2012), this type of regionalism works against the hemispheric integration spearheaded by the USA, which was viewed as 'neoliberal,' as well as the 'open regionalism' of the 1990s.

Post-hegemonic regionalism and the ascent of governments with a nationalist-progressive orientation is largely derived from the anti-globalisation movements at the end of the 1990s, following successive financial crises in developing countries such as Russia, Argentina, Brazil, and the Asian Tigers. There were many different international reactions to the supposed diverse consequences of globalisation and the influence of the USA and IMF. One example was the 'Battle of Seattle' on 30 November 1999 when 40000 demonstrators confronted leaders of the developed and industrialised world at the WTO Ministerial in the USA in protest against economic globalisation. As noted by Estevadeordal (2012: 23), '... some governments in Latin America, pressured by a public backlash against globalization, turned their backs on open trade policies.' As a result, Latin American regionalism became 'less focused on economic liberalisation, and more political in its orientation' (Nolte and Wehner 2013: 3).

In 2010, the Brazilian minister of foreign affairs, Celso Amorim, declared that the terms of the FTAA negotiations did not chime with Brazilian interests. This included favouring negotiations about services, government purchases, and foreign investment, rather than agricultural subsidies and anti-dumping measures (Amorim 2010). As a result, numerous Latin-American countries came to prefer more autonomous processes of integration. Brazil opted for a multilateral strategy via cooperation with its neighbours, with South American integration a primary foreign policy objective (Garcia 2008). ${ }^{4}$

Brazil's new-found aversion to hemispheric integration might also have been driven by its desire to become a regional leader. While, for political and diplomatic reasons, it did not say so openly, the Brazilian government believed the failure of the FTAA negotiations worked in favour of South American integration under Brazilian leadership. Other South American leaders also adopted a more hostile attitude towards the USA. Given this, efforts began to establish a Union of South American Nations (UNASUL). 
As noted by Saraiva and Velasco Júnior (2016: 301), 'Lula’s foreign policy prioritized a South American order under Brazilian leadership, where Brazil would assume the central responsibility for the integration and regionalization process.' Mercosur also began to extend its agenda beyond the purely commercial one of the 1990s, resulting in the establishment of the Fund for Structural Convergence (FOCEM) and the Parliament of the Mercosul (PARLASUL).

While there are objective reasons for Brazilian regional leadership, including its huge size, and it status as the largest economy in Latin America, subjective elements related to the recognition and broad acceptance of its leadership are lacking (Malamud 2011). For example, Argentina and Colombia have not supported Brazil's efforts to gain a seat in the UN Security Council. Moreover, as Spektor (2010: 29) points out, other governments and people in the region do not necessarily believe it would be a 'friendly leader.'

While Dilma Rousseff's government sought to maintain the institutions for regional governance formulated and/or consolidated by the Lula government (Saraiva and Velasco Júnior 2016: 301), it increasingly failed to do so. Faced with serious internal economic and political crises, as well as international conditions which were less favourable to Brazilian insertion, it became more engaged with domestic issues. Cervo and Lessa (2014) refer to this moment (2011-2014) as 'the decline of Brazil within international relations', pointing to a growing inability to maintain external linkages and sustain international relations.

Given this, I argue that conditions did not favour Brazil's ascent to regional leadership in the context of more heterogeneous and autonomous regional integration, reaching beyond Mercosur. I also argue that the constitution and development of the PA express this heterogeneity, as well as the failure of Brazilian aspirations.

\section{The emergence of the Pacific Alliance}

The collapse of the FTAA seemed to reduce prospects for introducing and regulating continent-wide 'rules of origin' and for USA ties in Latin America. However, the USA still managed to keep up or conclude trade agreements with more globalist and market-oriented Latin American countries, such as Costa Rica, Panama, Colombia, Peru and Chile.

Following the proliferation of trade agreements in Latin America, along with foreign policy shifts, it becomes possible to identify three types or models of regional integration (Nolte and Wehner 2013; Riggirozzi and Tussie 2012). The first is 'trade-driven,' and features agreements with a strong emphasis on commerce and investment. While this model does not imply deeper levels of political integration, it has the potential to develop into commercial multilateralism. Examples are NAFTA, the PA, and the failed FTAA.

The second is a 'hybrid' model, also regarded as 'state-driven' or 'state-led, which combines commercial cooperation with greater state economic intervention, as well as goals stretching beyond trade. Examples are UNASUL (partly in crisis due to the voluntary suspension of some states), the Andean Community (CAN) (partly obsolete due to the exit of Venezuela in 2006 and the creation of the PA), the Central American Integration System (SICA), the Caribbean Community (Caricom), and Mercosur. 
The third model emphasises social and political bonds among member states, involves considerable state economic intervention, and is driven by socialist, anti-imperialist, or anti-hegemonic ideas. The main example is the Bolivarian Alliance for the Peoples of Our America (ALBA), led by Venezuela, and created in explicit opposition to the FTAA (Nolte and Wehner 2013: 3; Riggirozzi and Tussie 2012: 11).

In principle, at least, South America has moved towards becoming a free trade area, most notably through the Economic Complementation Accords among member states of Mercosur and the Andean Community, negotiated under the Latin American Integration Association (ALADI). However, the new commercial issues, such as the non-tariff barriers and trade in services, and possible 'trade and investment diversion' among subregional blocs (see Viner 1950) have increased the complexity of regional integration, and relativised the notion of an authentic free trade area by simply reducing tariffs.

In the context of global economic shifts and new regionalisms, the PA has gained prominence as a renewed attempt to establish a commercial bloc. Based on a conjunction of objectives with a focus on market economics, and incorporating a large number of previous Free Trade Agreements (FTAs), it has attracted growing attention from markets, the media, and critics.

The initiative began in 2010 when the former Peruvian president Alan García Pérez invited the presidents of Chile, Colombia, Ecuador, and Panama to establish an Area for Deep Integration, encompassing political, economic and technical cooperation. Essentially, it was aimed at enabling Latin America to compete more effectively towards the Asia-Pacific region, one of the most economically and financially dynamic regions in the world (Ministry of Economy (Mexico) 2012). Ecuador did not respond to the invitation, emphasising its proximity to other blocs such as ALBA and Mercosur. Panama participated as an observer, with the idea that it would eventually become a full member. Chile and Colombia expressed their desire for Mexico to become part of the initiative, which shares a certain degree of economic and pro-market policy inclinations with the three other countries, which was accepted by Peru (Ministry of Economy (Mexico) 2012).

In June 2012, the Alliance gained a legal personality when the presidents of Chile, Colombia, Mexico and Peru signed a Framework Agreement, supported by the Presidential Declaration of Paranal, in which they reaffirmed their intention to promote mutual trade and investment. A free trade and economic integration agreement was signed in 2014, and took effect in 2016.

The formation of the bloc has attracted significant international attention, including more than 50 observer states from five continents. It has also notched up some achievements in its relatively short life. This includes the Latin American Integrated Market (Mercado Integrado Latino Americano, or MILA) of 2011, which integrates the stock markets of the four founding members. The Pacific Alliance Business Council provides business people with a platform for discussion and negotiation, besides cooperation among export promotion agencies. Joint embassies and business offices have been established in third countries. However, further advances will depend on political, economic and institutional progress in the medium and long terms. 
All four member countries have commercial agreements with the USA: an agreement with Mexico under NAFTA became effective in 1994; an agreement with Chile in 2004, with Peru in 2009, and with Colombia and Panama in May and December 2012. The USA officially supported the project.

In 2013, when the USA became an observer, the US Department of State lauded the initiative as an example for Latin American countries, stressing shared values such as a commitment to commercial liberalisation, and the extension of existing economic bonds among Chile, Peru and Mexico within the Trans-Pacific Partnership (TPP) negotiations (US Department of State 2013). In January 2017, however, President Donald Trump withdrew the USA from this mega-regional agreement, marking a turning point for the US government's stance on international trade. ${ }^{5}$

Consolidating the PA as a project for 'deep integration' is an enormous challenge, and there are no guarantees that this ambitious agenda will succeed. Earlier treaties among member states and among these members and third countries may limit the rate of growth of interregional trade. Furthermore, if productive integration is understood as one of the central characteristics of regional integration, this appears to be compromised by the lack of productive complementarily among its members. Chile, Colombia, and Peru largely export primary commodities and natural resource-intensive goods, while Mexico largely exports manufactured goods, and is inserted into North American value chains. Moreover, the geographic distance between Mexico and the three South American countries also functions as a natural obstacle to the development of joint production chains.

\section{Mercosur versus the Pacific Alliance}

The PA differs from Mercosur both in terms of member states as well as its objectives. Mercosur is commonly referred to as a 'commercial fortress', with highly restricted access to international markets, given the limited number of external trade agreements. Members may not negotiate individual trade agreements, as the bloc is actually an (imperfect) customs union. Moreover, the decision 'Conselho do Mercado Comum' No 32/00 has reaffirmed that member states may only negotiate joint trade agreements with third countries.

By contrast, the PA is an example of 'open regionalism,' which, ironically, was one of Mercosur's founding principles in the 1990s. This means that member states have greater freedom to formulate external commercial policies, whether on a multilateral, preferential (regional or bilateral) or unilateral basis. At the same time, this degree of freedom may compromise economic and political integration, as well as joint international commitments.

Mercosur has been criticised on the grounds that it reflects a bygone era. Its regulations need to be amended in order to overcome the main obstacles to economic integration, which are more complex than barriers to the flow of goods. The Common External Tariff (CET) is complex and problematic, especially in respect of the double taxation of goods imported internally from other member states, as well as the extensive list of exceptions. Moreover, Mercosur lags behind other blocs in taking account of the newer aspects of global trade, like investments, intellectual property, trade in services, and governmental 
purchases, and when it does, levels of commitment by member states are relatively low (Pereira 2013; Thorstensen and Ferraz 2014).

According to Lia Pereira (2013: 5), the failure of the FTAA negotiations and the Argentinian crisis of 2001 go some way towards explaining why Mercosur has delayed addressing these aspects, which are 'present in trade agreements of the new generation.' She also highlights that agreements between Mercosur and other South American countries - Chile, Bolivia, Colombia, Ecuador, Peru and Venezuela - are restricted to trade in goods (Pereira 2013: 5). However, the newer aspects of trade have become even more important due to the progress of the digital economy and the fourth industrial revolution, which requires greater regulatory efficiency, and the need for trade in advanced services.

Some international economic indices corroborate the contrast between the two economic blocs. Table 1 compares the PA and Mercosur in terms of two indicators, namely ease of doing business, and global competitiveness.

Table 1: Ease of doing business and global competitiveness

in the PA and Mercosur, 2016-2017

\begin{tabular}{|c|c|c|c|c|c|}
\hline \multicolumn{3}{|c|}{ Ease of Doing Business 2017} & \multicolumn{3}{|c|}{ Global Competitiveness Index 2016-2017 } \\
\hline Global Position & PA & Mercosur & Global Position & PA & Mercosur \\
\hline 47 & Mexico & & 33 & Chile & \\
\hline 53 & Colombia & & 51 & Mexico & \\
\hline 54 & Peru & & 61 & Colombia & \\
\hline 57 & Chile & & 67 & Peru & \\
\hline 90 & & Uruguay & 73 & & Uruguay \\
\hline 106 & & Paraguay & 81 & & Brazil \\
\hline 116 & & Argentina & 104 & & Argentina \\
\hline 123 & & Brazil & 117 & & Paraguay \\
\hline 187 & & Venezuela & 130 & & Venezuela \\
\hline
\end{tabular}

PA members outperform Mercosur members in terms of both indicators. Uruguay is Mercosur's best performer, ${ }^{6}$ and Venezuela its worst (in fact, in terms of ease of doing business, it is only ahead of Liberia, Eritrea and Somalia, which are affected by long-term conflicts and a loss of state control over their national territories). However, we need to note that, while protection can undermine competitiveness, radical liberalisation can also hinder deep integration with neighbouring countries, or even mask the failure of other domestic policies.

Regional integration and development are directly influenced by the macroeconomic policies of individual Latin American countries, as they tend to treat regional integration as a second or third priority in times of domestic convulsions. Table 2 lists annual GDP growth per capita and foreign trade as a percentage GDP of the nine Mercosur and PA member states over the period from 2005 to 2015. 
Table 2: Average growth per capita and foreign trade as \% of GDP in PA and Mercosur member states, 2005 to 2015

\begin{tabular}{lrll}
\hline GDP growth per capita (annual \%) & Trade (\% of GDP) & \\
\hline Uruguay & 4,7 & Paraguay & 99,1 \\
Peru & 4,6 & Chile & 69,9 \\
Colombia & 3,4 & Mexico & 61,5 \\
Paraguay & 3,4 & Uruguay & 54,8 \\
Chile & 2,7 & Venezuela & 51,4 \\
Argentina & 2,7 & Peru & 51,2 \\
Venezuela & 2,1 & Colombia & 37,0 \\
Brazil & 1,8 & Argentina & 34,2 \\
Mexico & 1,0 & Brazil & 25,2 \\
\hline
\end{tabular}

Source: Compiled by the author, based on World Bank data. Data for Venezuela stretches up to 2014.

It shows that there is no clear correlation between foreign trade (as \% of GDP) and economic growth. For example, while Brazil was the second-worst performer in terms of income growth, and the most closed economy, Mexico was the worst performer in terms of income growth, while trade accounted for more than $60 \%$ of GDP. However, Brazil's poor economic performance may be one of the reasons for its poor trade performance, and vice versa, and Mexico might have experienced specific problems surrounding its exports, notably in improving its positioning in regional and global value chains.

As regards trends, while Mexico's overall growth performance was the worst, it achieved 1,8\% growth in the post-crisis period of 2010-2015, compared to close to zero in the first five years. Brazil, on the other hand, did better in 2005-2009 (2,5\% average growth) than in 2010-2015 (1,2 \% average growth), largely due to the biggest economic crisis in its history. Countries tend to encourage or discourage regional integration in line with domestic conditions, or perceptions of what would favour domestic growth.

The low growth levels in Brazil and Mexico, in parallel with their political and institutional problems, may reduce their willingness or ability to effectively lead Latin American integration, even though they are the largest economies in Mercosur and the PA respectively. In fact, major economies, which should be more mature, displayed lower rates of growth than smaller economies. In Colombia, an exception to the general pattern, higher levels of institutional stability were rewarded by higher rates of economic growth.

Table 3 reflects GDP growth per capita for Mercosur and the PA in the decade from 2005 to 2015. It shows that average growth for both blocs over the whole period was practically the same. However, while 'Mercosur without Venezuela' grew more rapidly over the whole period than the PA, the PA grew more rapidly in the second period, while Mercosur, especially 'without Paraguay and Uruguay', grew more slowly. This shows that PA members did better during and after the international financial crisis than Mercosur members, which contradicts the notion that they should have been more vulnerable as they were more exposed to global flows of trade. 
Table 3: GDP growth per capita in the PA and Mercosur, 2005-2015

\begin{tabular}{llll}
\hline Average GDP growth per capita (\%) & $\mathbf{2 0 0 5}$ to 2009 & $\mathbf{2 0 1 0}$ to $\mathbf{2 0 1 5}$ & $\mathbf{2 0 0 5}$ to $\mathbf{2 0 1 5}$ \\
\hline Pacific Alliance & 2,8 & 3,1 & $\mathbf{2 , 9 3}$ \\
Mercosur & 3,6 & 2,3 & $\mathbf{2 , 9 2}$ \\
Mercosur without Venezuela & 3,3 & 3,0 & $\mathbf{3 , 1 3}$ \\
Mercosur without Paraguay and Uruguay & 3,6 & 0,9 & $\mathbf{2 , 1 9}$ \\
\hline
\end{tabular}

Source: Compiled by the author, based on World Bank data. Data for Venezuela stretches up to 2014.

Overall, the tables show that the different approaches embedded in these two integration projects did not result in significantly different levels of per capita growth. International experience suggests that they should seek to improve levels of cooperation. Moreover, the convergence in performance terms between the PA and Mercosur may enhance opportunities for integration, even though political differences may remain.

\section{Brazilian exports to Mercosur and the PA}

Internationally, Latin American countries continue to compete against China, although less so than in the 2000s. According to Ray and Gallagher (2015: 2), in 2008-2013, 75\% of the region's exports of manufactured goods faced threats from China, compared to $83 \%$ in 2003-2008. Nonetheless, we argued that, given Chinese trade and investment agreements with those countries, China's competition with regional suppliers of industrialised products, such as Brazil and Mexico, was set to intensify. However, Baumann (2013) has argued that the search for productive complementarities in Latin America may well help the region to become more competitive internationally, and achieve higher levels of economic growth.

Latin America has been an important market for Brazilian value-added goods, absorbing some $44 \%$ of total Brazilian exports of manufactured goods in 2017. But this is partly due to Mercosur's CET, trade preferences within ALADI, as well as Brazil's lack of competitiveness in other markets. Some analysts argue that the Mercosur CET has created a 'reserved market,' not least with regard to motor vehicles, and that high levels of regional trade in Brazilian goods do not necessarily reflect their international competitiveness. Moreover, even though Latin America may be Brazil's most important market, there is nothing that stops other countries outside Mercosur from concluding trade agreements with third countries.

Cheap Chinese products have already threatened Brazil's traditional regional market. Moreover, China may well use its agreements signed with Argentina since 2015 in various fields, including the telecommunications, agricultural and hydroelectric sectors, to push the latter country towards preferential trade, which would intensify competition with Brazilian exports.

If other Mercosur member states start importing more goods from China rather than from Brazil, this may also happen in other regions, where Brazilian goods are less protected. Table 4 reflects imports by Mercosur and PA member states from Brazil, China and the USA in three five-year periods. 
Table 4: Imports by Mercosur and PA member states from Brazil, China and the USA in 2005, 2010 and 2015

\begin{tabular}{|c|c|c|c|c|c|}
\hline \multicolumn{6}{|c|}{ Imports from Brazil (US\$ million) } \\
\hline & 2005 & 2010 & 2015 & Var.2010 - $2015 \%$ & Var. $2005-2015 \%$ \\
\hline Argentina & 9.930 & 18.523 & 12.800 & $-30,9$ & 28,9 \\
\hline Paraguay & 963 & 2.548 & 2.473 & $-2,9$ & 156,9 \\
\hline Uruguay & 853 & 1.531 & 2.727 & 78,1 & 219,6 \\
\hline Venezuela & 2.224 & 3.854 & 2.987 & $-22,5$ & 34,3 \\
\hline Chile & 3.624 & 4.258 & 3.978 & $-6,6$ & 9,8 \\
\hline Colombia & 1.412 & 2.196 & 2.115 & $-3,7$ & 49,8 \\
\hline Mexico & 4.074 & 3.715 & 3.588 & $-3,4$ & $-11,9$ \\
\hline Peru & 939 & 2.021 & 1.816 & $-10,1$ & 93,4 \\
\hline \multicolumn{6}{|c|}{ Imports from China (US\$ million) } \\
\hline & 2005 & 2010 & 2015 & Var. $2010-2015 \%$ & Var. $2005-2015 \%$ \\
\hline Argentina & 1.324 & 6.116 & 8.805 & 44,0 & 564,8 \\
\hline Brazil & 4.827 & 24.461 & 27.412 & 12,1 & 467,9 \\
\hline Paraguay & 253 & 1.051 & 1.268 & 20,7 & 402,0 \\
\hline Uruguay & 283 & 1.478 & 1.961 & 32,7 & 593,8 \\
\hline Venezuela & 908 & 3.649 & 5.316 & 45,7 & 485,5 \\
\hline Chile & 2.149 & 8.025 & 13.290 & 65,6 & 518,3 \\
\hline Colombia & 930 & 3.820 & 7.581 & 98,5 & 715,0 \\
\hline Mexico & 5.538 & 17.873 & 33.792 & 89,1 & 510,2 \\
\hline Peru & 609 & 3.550 & 6.355 & 79,0 & 943,7 \\
\hline \multicolumn{6}{|c|}{ Imports from the USA (US\$ million) } \\
\hline & 2005 & 2010 & 2015 & Var. $2010-2015 \%$ & Var. $2005-2015 \%$ \\
\hline Argentina & 4.122 & 7.392 & 9.341 & 26,4 & 126,6 \\
\hline Brazil & 15.372 & 35.418 & 31.651 & $-10,6$ & 105,9 \\
\hline Paraguay & 896 & 1.810 & 1.514 & $-16,3$ & 69,0 \\
\hline Uruguay & 357 & 975 & 1.295 & 32,8 & 263,1 \\
\hline Venezuela & 6.421 & 10.645 & 8.346 & $-21,6$ & 30,0 \\
\hline Chile & 5.134 & 10.907 & 15.445 & 41,6 & 200,9 \\
\hline Colombia & 5.462 & 12.068 & 16.287 & 35,0 & 198,2 \\
\hline Mexico & 120.248 & 163.665 & 235.745 & 44,0 & 96,0 \\
\hline Peru & 2.309 & 6.750 & 8.726 & 29,3 & 277,8 \\
\hline
\end{tabular}

Source: Compiled by the author, based on MDIC (2017); China Statistical Yearbook (2016); US Census Bureau International Database (2017). 
Even though 2015 was a year of crisis in Brazil, which impacted significantly on foreign trade, it is still possible to draw some meaningful conclusions. ${ }^{7}$

Mercosur and PA imports from China rose massively over the whole period, far more so than from Brazil. Imports from Brazil also flattened out significantly from 2010 to 2015, with all countries except Uruguay importing fewer Brazilian goods.

Mercosur and PA imports from the USA also rose significantly over the whole period, more so than Brazilian imports, and more so for the PA than for Mercosur. From 2010 to 2015, US exports to three Mercosur countries - Paraguay, Brazil and Venezuela - diminished, reflecting the economic crises in the two last-named countries, while exports to Argentina and Uruguay increased. As can be expected, USA exports to all four PA countries grew significantly.

The most notable feature may be Brazil's trade with Argentina. While in 2010 to 2015, imports from Brazil dropped massively, Chinese and US imports increased by $44 \%$ and $26 \%$ respectively.

\section{The need for regional integration and decentred economic regionalism}

Figures 1 and 2 record the trade balances for both PA and Mercosur member states from 2000 to 2015. Up to the financial crisis in 2007-2008, most countries showed healthy and growing trade surpluses, largely due to growing Chinese demand for primary products. From then onwards, trade balances declined, largely due to reduced demand for metals and minerals and lower prices for agricultural commodities as well as oil (World Bank 2017).

Figure 1: External balance of goods and services for PA member states, 2000-2015 (\% of GDP)

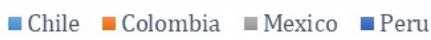

15

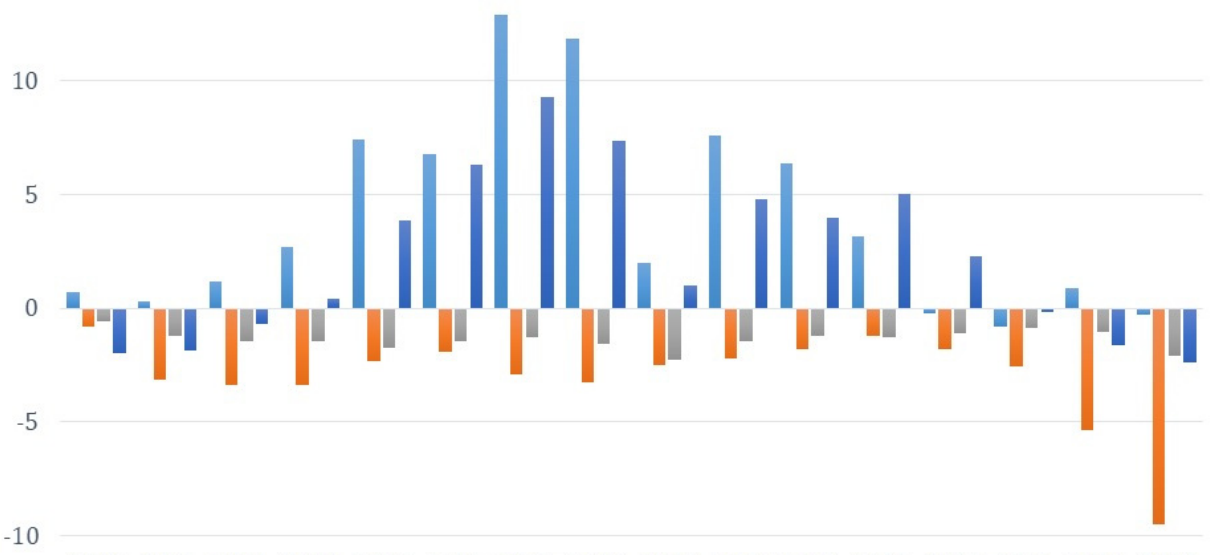

2000200120022003200420052006200720082009201020112012201320142015

Source: Compiled by the author, based on World Bank data. 
Figure 2: External balance of goods and services for Mercosur member states, 2000-2015

(\% of GDP)

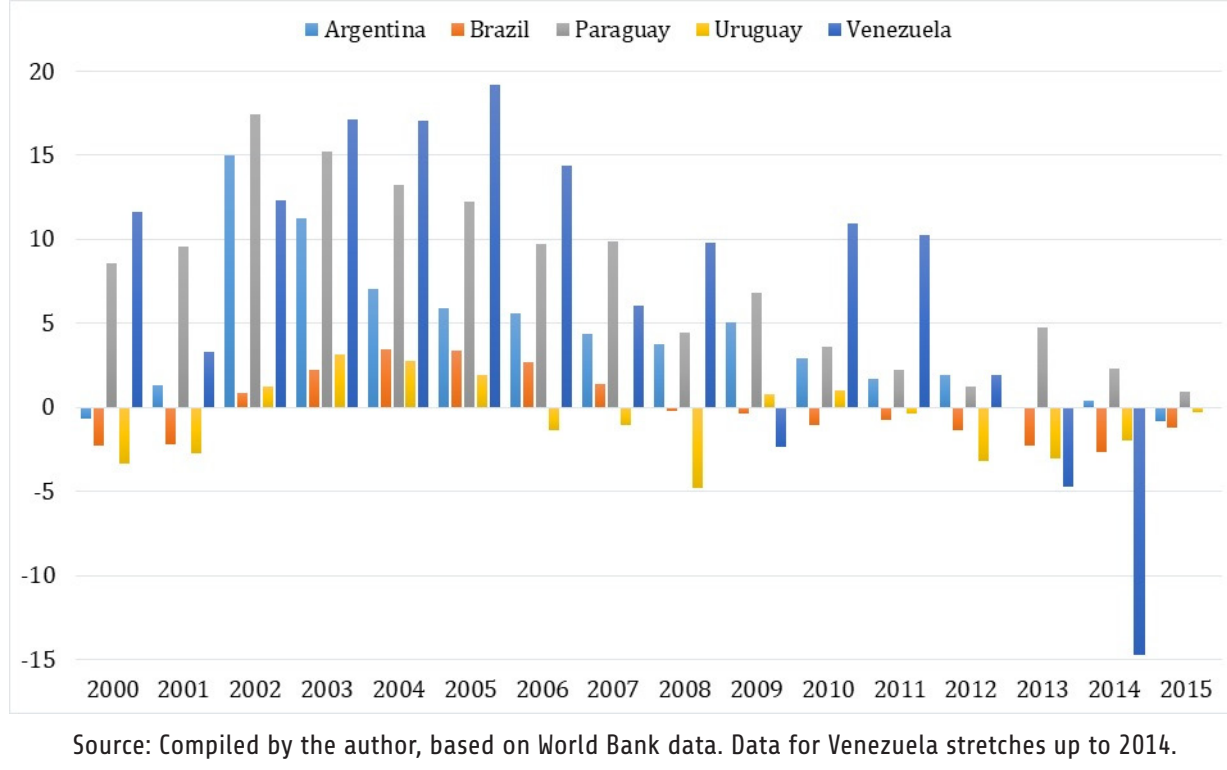

Commodity markets are very volatile, which makes it difficult for countries that depend upon selling primary products to plan their economic futures. A drop in the prices of manufactured goods - possibly due to improved productivity, and to low production costs in East Asia - and an increase in the prices of primary goods due to the global commodity boom contributed to the trade surpluses of Mercosur and PA member states.

However, following the reasoning of Raúl Prebisch in respect of the $20^{\text {th }}$ century, even when countries exporting primary products benefit from increases in international demand and therefore higher prices, the terms of trade of primary goods (whose prices would show a smaller marginal increase) will continue to deteriorate in the longer term, relative to those of manufactured goods (CEPAL 2017). Moreover, it could make these countries more dependent on primary exports. By contrast, promoting the integration of Latin American markets could promote industrialisation in the region, improving their insertion into the global economy as well.

In fact, as noted by Feenstra (1998), global trade is largely concentrated within relatively similar industrialised economies, and takes place through inter- and intra-industrial trade and exchanges of intermediate products. By contrast, specialising in the production of primary commodities without significant links to the industrial and services sectors tends to reduce a given country's ability to insert itself into regional and global value chains, which increases the costs of acquiring new knowledge, know-how, and production models. Put differently, the extraction of primary commodities tends to provide less 'production slicing' than sectors with a higher technological content.

Mercosur and the PA could reduce the region's exposure to exogenous price fluctuations by becoming more integrated. According to the WTO (2015), intra-regional trade 
in South and Central America amount to about $25 \%$ of total trade, which is very low. In regions where the bulk of value chains are concentrated - notably Europe (68,5\%), Asia $(52,3 \%)$, and North America (50,2\%) - levels of intra-regional trade are far higher.

Successful regional complexes tend to have lead countries that play a central role in the entry of intermediate goods from other members of the same integration scheme. This process is marked by feedback loops, which make it possible to reduce production costs and to benefit from reduced distances for commercial exchanges. In South America, however, these dynamics are still at an early stage. As we noted in a previous work (Viola and Lima 2017), the Mercosur integration model is 'introspective,' with little effort made towards encouraging productive and technological complementarity among member states in order to improve their global engagement, which would make trade integration more sustainable in the longer term. Mercosur has also few agreements and few productive connections with the rest of the world.

Following Trump's rise to the US presidency, and the new emphasis on economic nationalism and mercantilism, the USA is increasingly questioning its trade relations with Latin American countries, especially with Mexico under NAFTA. Even the Obama government no longer saw Latin America as a priority. ${ }^{8}$ Given this, it has become even more important for Latin American countries to cooperate with one another, as US investment and development assistance may diminish. Moreover, regional integration could play a vital role in promoting the growth of Latin American economies.

Following Buzan (2011), the contemporary international order is marked by a plurality of capitalisms, the end of the age of superpowers, a more regionalised order, and a dense interdependence, which he describes as 'decentred globalism.' He goes on to note that: '[A] world with only great powers is likely to take a more regionalized form; this might produce a quite workable, decentralized, coexistence of international society with some elements of cooperation' (Buzan 2011:3).

He goes on to say that 'the social foundations for a regionalized order start from a strong anti-hegemonism [...] expressed in widespread calls for a more multipolar international system' (2011: 16), and that 'tensions over hegemonic interference would decline if regions were, for better or worse, more in charge of their own affairs' (Buzan and Lawson 2014: 91). Thus, regionalism also becomes a strategy for global engagement, with powerful nations such as Brazil, Russia and China also identifying opportunities for seizing or reinforcing their roles as regional powers or leaders. Often, however, their smaller neighbours have been less enthusiastic about these aspirations.

By contrast, regional integration in Latin America is heterogeneous, with no single state leading or controlling the integration process, or persuading neighbouring states to accept its integration strategy. This contrasts with much of what Brazil wanted in the first decade of the $21^{\text {st }}$ century. The new era or post-hegemonic or post-liberal regionalism emphasised the pursuit of autonomous regional integration without interference from outside powers, especially the USA. Given its economic growth in the early 2000s, and the collapse of the FTAA, Brazil saw an opportunity to establish itself as a regional leader, albeit in the context of post-hegemonic regionalism. The very emergence of the 
PA - whose members conclude free trade agreements with the USA, adopt more liberal political economic models than their Atlantic neighbours, and have partly reinvigorated open regionalism - suggests that Brazil lacks regional followers for this strategy.

There is, in fact, an anti-hegemonic sentiment in Latin America, manifested not only towards developed countries, but also towards more powerful countries in the region. That is, the asymmetries in Latin America, notably the status of Brazil and Mexico as the largest countries with the biggest economies and the most prominent members of two regional integration schemes, have become obstacles to more effective regional integration. Their poor economic growth in the period under review and the improved growth of smaller countries have worked to empower the latter politically, and fostered a more democratic and decentralised regionalism.

As regards productive complementarity - which is still poorly explored and exploited in Latin America compared to East Asia, for example - 'core-periphery' relations become important. Unlike traditional patterns of power and coercion, such a relationship should be arranged around virtuous networks, flows and connections, with bigger economies in the region fostering the performance of smaller ones, and with regional integration seen as means of making its countries more globally competitive. In this perspective, commercial, productive, and, above all, knowledge flows among nations become far more important than positive trade balances. They could even help countries to advance in terms of high technology and artificial intelligence, the sources of future economic growth (Ovanessoff and Abbosh 2017).

It is clear that Latin America exhibits a 'decentred regionalism, due to the lack of a single nation with the desire, power, and followers to assume leadership and establish a predominant conception of regional integration. Despite this heterogeneity, there is a need for higher levels of cooperation among its regional blocs, aimed at enhancing the global competitiveness of the region as a whole. This requires cooperation rather than enforcement, and networks and connectivity rather than hierarchies.

\section{Final considerations}

Latin America is a remarkable example of how the concept of a region is not geographically determined, but shaped and reshaped by interactions among various regional actors, subject to international influences. The diverse regionalisms present in Latin America illustrate this vividly. Therefore, this article also serves as a historical record of the place of Latin America in a world in constant transformation, and at a particular moment of diversity.

Some economic logics of regionalism must be highlighted, although they are not often present in political logics. If trade agreements have the potential to 'divert' trade and investment from other countries and other regions, while not necessarily creating new trade flows, cooperation and even integration among regional blocs become important issues. It is clear that a lack of cooperation among developing countries such as those 
in Latin America makes them more vulnerable to and dependent on international trade dynamics.

Coordinating collaboration among countries in diverse and heterogeneous regions is not an easy task, especially when they harbour divergent ideas about their national and regional goals, and how to achieve them. However, it is even more important to govern regionalism for its developmental benefits than its political ones. All integration initiatives face these challenges. When Trump speaks about the need to change international migration and labour regimes, he constantly speaks about NAFTA. Although he has stated that joining NAFTA would harm the USA, it is Mexico that remains at the lowest end of the North American value chain, with far-reaching social consequences. Following the 20072008 financial crisis and the subsequent Euro crisis, the European Union has had to deal with numerous challenges including Brexit, debt renegotiations in peripheral European countries, and monetary integration without fiscal integration.

Political coordination is needed to address these challenges, and to reduce the endemic asymmetries among neighbouring countries. While centripetal forces have grown too, regional concerts are a good way to deal with globalisation, confronting its adverse effects and capturing its benefits, and to assist qualified regional insertion into a rapidly changing global economy.

\section{Notes}

1. 'Latin America' is taken to mean South and Central America plus Mexico. While this term is ideologically laden, and sometimes contested, its scope is embedded in the Pacific Alliance as well as organisations such CELAC, which dictates its use for practical reasons.

2. The suspension of some Member States and the lack of consensus in the organisation reinforce the evidence of uncoordinated regional heterogeneity.

3. This has been the subject of some notable books, including Riggirozzi and Tussie (2012) and Vivares (2018).

4. Besides the preferences for South American integration one of the reasons why Brazil did not support the advance and consolidation of the FTAA was the emphasis on multilateral negotiations through the Doha Round under the World Trade Organization which was launched in 2001.

5. In April 2018, adding another chapter to the story, Republican senators stated that the USA might reconsider its stance on the TPP, which could be seen as a way of exerting pressure on China on negotiations over trade and technology policies.

6. It is clear from the indicators that Uruguay is the most open country in Mercosur. Interestingly, in 2007, Uruguay signed a Trade and Investment Framework Agreement with the USA, which could be a precursor to a free trade agreement, which would conflict with the Mercosur Customs Union in turn.

7. A three-year analysis is used to outline and evaluate Brazil's trade preferences, but a more detailed analysis of a broader historical series including other variables may be needed to corroborate it.

8. This was mainly due to the USA's 'Pivot to Asia' policy, a major initiative under which it sought to build closer relations with India and the countries of East Asia. This was aimed at helping to diversify US interests beyond Europe and the Middle East, and possibly to counterbalancing Chinese influence in Asia. On the other hand, the Obama administration promoted the historic US rapprochement with Cuba, even though this has been reviewed by the Trump government. 


\section{References}

Acharya, A. 2012. 'Comparative regionalism: A field whose time has come?' The International Spectator: Italian Journal of International Affairs 47 (1): 3-15.

Amorim, C. 2010. 'Brazilian foreign policy under President Lula (2003-2010): an overview.' Revista Brasileira de Política Internacional 53 (special edition): 214-240.

Ayerbe, L F (ed). 2008. Novas Lideranças Políticas e alternativas de governo na América do Sul. São Paulo: Unesp.

Baumann, R. 2013. Integração Regional: Teoria e Experiência Latino-Americana. Rio de Janeiro: LTC. Brazilian Government [online]. 2017. 'Comércio Exterior.' Ministry of Development, Foreign Trade and Services (MDIC). At http://www.mdic.gov.br/comercio-exterior [Accessed on 15 June 2017].

Buzan, B. 2011. 'A world order without superpowers: decentred globalism.' International Relations 25(1): 3-25.

Buzan, B and G Lawson. 2014. 'Capitalism and the emergent world order'. International Affairs 90 (1): 71-91.

Cervo, A L and A C Lessa. 2014. 'O declínio: inserção internacional do Brasil (2011-2014)'. Revista Brasileira de Política Internacional 57 (2): 133-151.

Chinese Government [online]. 2017. Statistical Yearbook 2016. At http://www.stats.gov.cn/english/ [Accessed on 15 September 2017].

Comisión Económica para América Latina y el Caribe (CEPAL). 2017. 'Términos de intercambio: Raúl Prebisch y los desafíos del Siglo XXI. Bibliguías - Bibliotecas CEPAL. Naciones Unidas, Comisión Económica para América Latina y el Caribe.

Devlin, R and P Giordano. 2004. 'The old and new regionalism: Benefits, costs, and implications for the FTAA.' In A Estevadeordal, D Rodrik, A M Taylor and A Velasco (eds), Integrating the Americas: FTAA and Beyond. New York: Harvard University Press.

Estevadeordal, A. 2012. 'Economic Integration in the Americas: An unfinished agenda.' In Ted Piccone, Inés Bustillo, Antoni Estevadeordal, Jeffrey M Puryear, Tamara Ortega Goodspeed, Thomas A O’Keefe, Kevin Casas-Zamora, Lucía Dammert, Rubén Perina, Jaime Aparicio-Otero (eds), The Road to Hemispheric Cooperation: Beyond the Cartagena Summit of the Americas. Washington, DC: Brookings Institution, pp. 22-29.

Feenstra, R C. 1998. 'Integration of Trade and Disintegration of Production in the Global Economy' The Journal of Economic Perspectives 12 (4): 31-50.

Garcia, M A. 2008. 'A Opção Sul-Americana.' Interesse Nacional 1 (1): 22-28.

Herz, M and A R Hoffmann. 2004. Organizações Internacionais: História e Práticas. Rio de Janeiro: Elsevier.

Lima, M R Soares de. 2013. 'Relações interamericanas: a nova agenda sul-americana e o Brasil'. Lua Nova 90: 167-201.

Malamud, A. 2011. 'A leader without followers? The growing divergence between the regional and global performance of Brazilian foreign policy'. Latin American Politics and Society 53 (3): 1-24.

Ministry of Economy (Mexico). 2012. Unidad de Coordinación de Negociaciones Internacionales: Alianza del Pacífico. Mexico D.F. 
Nolte, D and L Wehner. 2013. 'The Pacific Alliance Casts Its Cloud over Latin America.' Hamburg: GIGA Focus International Edition 8.

Ovanessoff, A and O Abbosh. 2017. 'Artificial intelligence could help reverse Latin America's economic slowdown.' World Economic Forum. At https://www.weforum.org/agenda/2017/03/artificial-intelligence-could-help-reverse-latin-america-s-economic-slowdown/ [Accessed on 16 December 2017].

Pereira, Lia Vallz. 2013. 'A nova onda de regionalismo: uma reflexão sobre a agenda brasileira.' Mural Internacional 4 (1): 2-7.

Ray, R and K Gallagher. 2015. 'China-Latin America Economic Bulletin 2015 Edition.' Global Economic Governance Initiative, Discussion Paper 2015-9.

Riggirozzi, P and D Tussie (eds). 2012. The Rise of Post-Hegemonic Regionalism: The Case of Latin America. London/New York: Springer.

Saraiva, M and P A Velasco Júnior. 2016. 'A Política Externa Brasileira e o fim de ciclo na América do Sul: para onde vamos?' Pensamiento Propio 21 (44): 295-324.

Söderbaum, F. 2015. 'Early, Old, New and Comparative Regionalism: The Scholarly Development of the Field.' KFG Working Paper Series No. 64. Berlin: Kolleg-Forschergruppe (KFG) "The Transformative Power of Europe."

Spektor, M. 2010. 'Ideias de ativismo regional: a transformação das leituras brasileiras da região.' Revista Brasileira de Política Internacional 53 (1): 25-44.

Thorstensen, V and L Ferraz. 2014. 'O isolamento do Brasil em relação aos acordos e mega-acordos comerciais.' Boletim de Economia e Política Internacional 16: 5-17.

United States Census Bureau [online]. 2017. Foreign Trade Database. At https://www.census.gov/ foreign-trade/index.html [Accessed on 15 December 2017].

Department of State (USA). 2013. The United States Participation as an Observer to the Pacific Alliance. Washington, DC.

Viner, J. 1950. The Customs Union Issue. New York: Carnegie Endowment for International Peace.

Viola, E and J Santos Lima. 2017. 'Divergences Between New Patterns of Global Trade and Brazil/ Mercosur.' Brazilian Political Science Review 11(3): 1-31.

Vivares, E (ed). 2018. Regionalism, Development and the Post-Commodities Boom in South America. London: Palgrave MacMillan.

World Bank [online]. 2017. Doing Business 2017. At http://www.doingbusiness.org/rankings [Accessed on 14 July 2017].

World Economic Forum [online]. 2017. Global Competitiveness Report 2016-2017. At http://www3. weforum.org/docs/GCR2016-2017/05FullReport/TheGlobalCompetitivenessReport2016-2017_FINAL.pdf [Accessed on 16 July 2017].

\section{Acknowledgements}

The author is grateful to CAPES for a Doctoral grant, and to Niels Søndergaard and Riaan de Villiers for their great support in revising and editing this article. The author also would like to thank anonymous reviewers and editors for their valuable comments. 


\title{
About the author
}

Jean Santos Lima is a PhD candidate in International Relations at the University of Brasilia (IREL/UnB), where he has also lectured in Contemporary International Politics and Methods \& Techniques of Research. He holds a CAPES doctoral scholarship. He has worked at the Institute of Applied Economic Research (IPEA), and has worked at the Brazilian Agency for Industrial Development (ABDI) on a major EU technical cooperation project in Latin America, supporting the internationalisation of small and medium-sized Brazilian firms. His main research interests include Development, International Political Economy, Knowledge Economy Advancement, Regional Integration, and Latin American challenges in the middle-income trap.

\section{Regionalismo Econômico Descentrado na América Latina: Da ALCA à Aliança do Pacífico}

\begin{abstract}
Resumo: Nesse artigo, investigo o regionalismo Latino Americano do colapso do Projeto da ALCA à emergência da Aliança do Pacífico, no período de 2005 a 2015. Para a maior parte da pesquisa, utilizo os principais blocos econômicos da região, $o$ Mercosul e a Aliança do Pacífico, como unidades de análise. Os principais resultados identificados são de que, desde o colapso da ALCA, os processos de integração se tornaram mais heterogêneos; o Mercosul e a AP contrastam um com o outro em termos político-econômicos; o projeto brasileiro de estabelecer um regionalismo pós-liberal/pós-hegemônico na América do Sul não teve sucesso; e que a demanda regional por produtos brasileiros está em risco de deslocamento a outros mercados no médio para longo prazo, debilitando ainda mais suas aspirações de liderança regional. Tudo isso evidencia o regionalismo econômico descentrado - isto é, uma forma de regionalismo na qual não há um único Estado no seu comando central, ou com seguidores suficientes para assumir uma liderança e estabelecer uma concepção predominante de integração e cooperação regional. Outros fatores que contribuem para essa descentralização são o baixo desempenho econômico de Brasil e México, e a mudança de postura do governo dos EUA em relação às relações comerciais com a América Latina. Apesar disso, argumento que os países latino-americanos precisam fortalecer a cooperação dentro e entre esses blocos regionais, focando na promoção da sua competitividade global conjunta. Isso requer mais cooperação e democracia do que coerção, e mais redes e conectividade do que hierarquias.
\end{abstract}


Palavras-chave: Regionalismo; Integração regional; Crescimento; América Latina; Aliança do Pacífico; ALCA.

Received on 22 June 2017, and approved for publication on 9 April 2018.

\footnotetext{
(c) BY-NC https://creativecommons.org/licenses/by-nc/4.0/
} 